\title{
Algorithmic Trading Systems Based on Google Trends
}

\section{Gómez-Martínez, Raúl; Prado-Román, Camilo; De la Orden de la Cruz, María del Carmen}

Departamento de Economía de la Empresa, Universidad Rey Juan Carlos de Madrid

\begin{abstract}
In this paper we analyze five big data algorithmic trading systems based on artificial intelligence models that uses as predictors stats from Google Trends of dozens of financial terms. The systems were trained using monthly data from 2004 to 2017 and have been tested in a prospective way from January 2017 to February 2018. The performance of this systems shows that Google Trends is a good metric for global Investors' Mood. Systems for Ibex and Eurostoxx are not profitable but Dow Jones, S\&P 500 and Nasdaq systems has been profitable using long and short positions during the period studied. This evidence opens a new field for the investigation of trading systems based on big data instead of Chartism.
\end{abstract}

Keywords: Big data, behavioral finance, investors' mood, artificial intelligence, Bayesian network, Google Trends. 


\section{Introduction}

Algorithmic trading systems invest in financial markets in an unattended and constant way, sending buy and sell orders to the market for a financial instrument, according to a complex mathematical algorithm. Most of the trading systems that are operating nowadays follows Chartism rules, but the irruption of big data in asset management has opened a new approach for algorithmic trading.

There are numerous studies that demonstrate that investor mood is affected by multiple factors, changes over time and may be conditioned by experience or training (Cohen and Kudryavtsev, 2012). These changes in mood provide evidence of anomalies in the behavior of stock markets (Nofsinguer, 2005). Corredor, Ferrer and Santamaría (2013) claim that investor mood has a significant effect on stock performance.

We find that weather affect to the stock market returns (Hirshleifer and Shumway, 2003, Jacobsen and Marquering, 2008) as sunny climates are associated with an optimistic mood and then positive returns. Seasonal patterns like vacations that implies the effect of "sell in May and go away" or the "Halloween" effect (Bouman and Jacobsen, 2002; Marshall 2010) means that securities market yield should be greater from November to April than from May to October. Even the Moon (Yuan, Zheng and Zhu, 2006) implies different returns according to the different phases of the moon observing differences from 3\% to 5\% in yield from one phase to another.

The sports results are another item that modifies investors mood. Edmans, García and Norli (2007) studied the results of football, cricket, rugby and basketball and others have focused on the NFL (Chang, Chen, Chou and Lin, 2012), football (Berument, Ceylan and Gozpinar, 2006; Kaplanski and Levy, 2010) and on cricket (Mishra and Smyth, 2010). Gómez and Prado (2014) performed a statistical analysis of the following stock markets session return after national team football matches. The results obtained show that after a defeat of the national team, we should expect negative and lower than average prices on the country's stock market, the opposite occurring in the case of a victory.

At this stage, if investor mood varies and affects financial markets and their liquidity (Liu, 2015), the challenge that arises is how to measure mood to predict market trend (Hilton, 2001) which leads us to consider a Big Data approach:

Wu et al. (2013) use big data to predict market volatility, Moat et al. (2013) use the frequency of use of Wikipedia to determine investor feelings, whereas Gómez (2013) elaborated a "Risk Aversion Index" based on the stats of Google Trends for certain economic and financial terms that relate to market growth. Through an econometric model, he shows that Google Trends provide relevant information on the growth of financial markets and may generate investment signs that can be used to predict the growth of major 
European stock markets. According to this approach, we could create an algorithmic trading system that issues buy and sell orders by measuring the level of aversion to risk, if an increase in tolerance towards risk implies a bull market and an increase in aversion to risk a bear market.

In this paper we will describe Big Data trading algorithmic systems that, instead of Chartism rules, use Artificial Intelligence (AI) models based on Google Trends to predict de evolution of main world stock index.

\section{Methodology and Hypothesis}

The following statistics are mainly used to measure the perform of an algorithmic trading system (Leshik and Crall, 2011):

- Profit/Loss: the total amount generated by the system from its transactions over a certain period.

- Success rate: Percentage of successful transactions out of the total transactions, if if the percentage is above $50 \%$, the system is profitable and the higher the percentage, the better the system.

- Profit Factor: this rate shows the relationship between earnings and losses, by dividing total earnings by total losses. A rate higher than 1 implies positive returns and the higher the rate, the better.

- Sharpe Ratio: relates profitability to volatility, the higher the ratio, the better the performance of the system (Sharpe, 1994).

InvestMood $^{1}$ developed in January 2017 trading algorithmic systems for the following index: Ibex 35, Eurostoxx 50, Dow Jones, S\&P 500 and Nasdaq.

According to Gomez (2013), the volume of searches registered in Google on financial terms has explanatory capacity and predictive on the evolution of the markets. Since 2004 in which Google Trends began to publish these statistics, it is observed that bearish markets imply high level of searches of terms such as crash, recession or short selling, while bull markets imply low levels of this searches. Bearing this in mind, InvestMood have created big data algorithmic trading systems that open long or short positions following an artificial intelligence model in which the predictors are Google Trends stats while the target variable is the next evolution of those index (up / down).

The process of the algorithm is the following one: Every first day of the month these systems trains the artificial intelligence models, using a monthly sample of Google Trends

\footnotetext{
${ }^{1}$ For mor information visit: http://www.investmood.com/
} 
of dozens of economic-financial terms, and issue a prediction for next month's trend. Google Tends consults have been limited to financial matters and don not have any restriction by localization. The system maintains a long or short open position until there is a new prediction in the opposite direction.

From this point, the hypothesis to study is the following one:

H1: A big data algorithmic trading system based on artificial intelligence models over investors' mood can generate positive returns.

We will validate this hypothesis if we reach three evidences:

1. Profit/Loss amount is positive including license costs and trading commissions.

2. Success rate is higher than $50 \%$

3. Profit factor is higher than 1

\section{Data}

Goggle Trends ${ }^{2}$ has historic data available from 2004 in a monthly base. As the first models was trained on 2017 , January $1^{\text {st }}$ the first models were trained using 156 observations.

The prospective analysis of this paper starts in January 2017 and ends in February 2018, so we have 14 months for the study and therefor 14 different models, each one for one month.

All the quotes and stats used in this study has been provided by Trading Motion. Trading Motion $^{3}$ is a Fintech who allows users of 23 brokers all over the world to operate in an unattended way using trading algorithmic systems developed by 74 professional developers. All these developers follow Chartism rules except InvestMood, that using the Rey Juan Carlos University has developed its systems using IA on Investors' Mood.

Trading systems studied in this paper are running on Trading Motion form January 2017. After three months testing the systems they were available for the clients for April 2017.

\section{Results}

The URL available for the stats of the systems concerning this study are:

Ibex 35: https://www.tradingmotion.com/explore/System/PerformanceSheet?Id=17652

Esx 50: https://www.tradingmotion.com/explore/System/PerformanceSheet?Id=17705

\footnotetext{
${ }^{2}$ Visit: https://trends.google.com/trends/

${ }^{3}$ For moro information visit: https://www.tradingmotion.com/
} 
DJ: https://www.tradingmotion.com/explore/System/PerformanceSheet?Id=17651

S\&P 500: https://www.tradingmotion.com/explore/System/PerformanceSheet?Id=17654

Nasdaq: https://www.tradingmotion.com/explore/System/PerformanceSheet?Id=17653

The models created for the trading systems has been trained using the algorithms of dVelox, a data mining tool developed by IT firm Apara ${ }^{4}$. These algorithms build a Bayesian Network (Bayes, 1763) like the following one, used for the Nasdaq model trained in 2018 February $1^{\text {st }}$ :

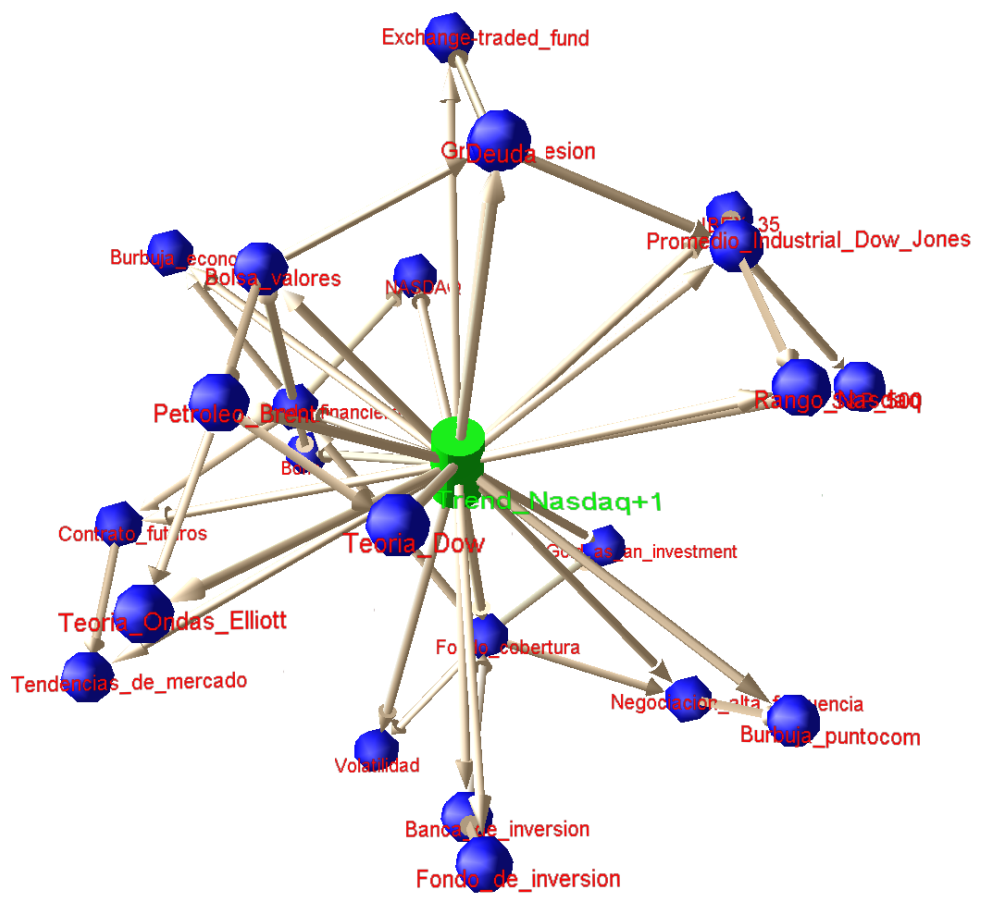

Figure 1. Bayesian Network for Nasdaq trading system. Source: dVelox (2018).

Table 1 sums up the performance of each one of the five trading systems that have been running form January 2017 to February 2018. In this table we observe that systems for Ibex and Eurostoxx are not profitable, so we cannot validate de $\mathrm{H} 1$ hypothesis for these indexes. Notwithstanding, the systems created for Dow Jones, S\&P 500, and Nasdaq has been profitable, they have a success rate higher than $50 \%$ and a profit factor higher than 1 , so we can validate $\mathrm{H} 1$ for this American indexes.

\footnotetext{
${ }^{4}$ For more information visit: http://www.apara.es/es/
} 
Table 1. Performance of Big Data trading algorithmic systems on Investors' Mood

\begin{tabular}{ccccc}
\hline Index & Profit/Loss & Success rate & $\begin{array}{c}\text { Profit } \\
\text { Factor }\end{array}$ & Sharpe Ratio \\
\hline Ibex 35 & $-824,00 €$ & $47,80 \%$ & 0,99 & $-0,64$ \\
Eursotoxx 50 & $-560,00 €$ & $50,50 \%$ & 1,00 & $-0,12$ \\
Dow Jones & $16.919,00 €$ & $58,20 \%$ & 1,36 & 1,52 \\
S\&P 500 & $20.803,00 €$ & $60,70 \%$ & 1,44 & 1,86 \\
Nasdaq & $34.628,00 €$ & $62.40 \%$ & 1,54 & 2,43 \\
\hline
\end{tabular}

Source: Trading Motion (2018)

\section{Conclusions}

In this study, we used an innovative approach to check the capability of the behavioral finance and the Investors' Mood to predict the evolution of the financial markets. The study is based on big data and uses artificial intelligence to predict the evolution of Ibex 35, Eurostoxx 50, Dow Jones, S\&P 500 and Nasdaq indexes. We can check that these "pure investors' sentiment" systems can be profitable for the American indexes while the result is poor for European ones.

First conclusion is that Google Trends is a good investors' sentiment metric for the American indexes studied, closer than global sentiment if Google Trends has been no limited by location. The poor results for Ibex or Eursotoxx suggests a limitation in Google Trends stats for this models in further investigation.

Second conclusion from this study is that trading systems can be developed using an alternative approach to common systems based on technical analysis. This study has shown how the trading system for Dow Jones, S\&P 500 and Nasdaq, based on the predictions of an artificial intelligence model that uses investors' mood from Google Trends to predict is capable to generate positive returns in a long/short strategy.

All this opens an interesting field of research in the development of algorithmic trading.

\section{References}

Bayes, T. (1763). An Essay towards solving a Problem in the Doctrine of Chances. Philosophical Transactions of the Royal Society of London 53: 370-418. doi:10.1098/rstl.1763.0053. 
Berument, H., Ceylan, N. B., y Gozpinar, E. (2006). Performance of soccer on the stock market: Evidence from turkey. The Social Science Journal, 43(4), 695-699. doi:10.1016/j.soscij.2006.08.021

Bouman, S., y Jacobsen, B. (2002). The Halloween indicator, "sell in may y go away": Another puzzle. The American Economic Review, 92(5), 1618-1635.

Chang, S., Chen, S., Chou, R. K., y Lin, Y. (2012). Local sports sentiment y returns of locally headquartered stocks: A firm-level analysis. Journal of Empirical Finance, 19(3), 309-318. doi:10.1016/j.jempfin.2011.12.005

Cohen, G. y Kudryavtsev, A., (2012). Investor Rationality y Financial Decisions. Journal of Behavioral Finance, 13(1), 11-16.

Corredor, P., Ferrer, E. y Santamaría, R. (2013): El sentimiento del inversor y las rentabilidades de las acciones. El caso español. Spanish Journal of Finance y Accounting, 42 (158), 211-237

Edmans, A., García, D., y Norli, Ø. (2007). Sports sentiment y stock returns. The Journal of Finance, 62(4), 1967-1998.

Gómez Martínez, R. (2013). Señales de inversión basadas en un índice de aversión al riesgo. Investigaciones Europeas De Dirección y Economía De La Empresa, 19(3), 147 157. doi:http://dx.doi.org/10.1016/j.iedee.2012.12.001

Gómez Martínez, R., y Prado Román, C. (2014). Sentimiento del inversor, selecciones nacionales de fútbol y su influencia sobre sus índices nacionales. Revista Europea De Dirección y Economía De La Empresa, 23(3), 99-114. doi:http://dx.doi.org/10.1016/j.redee.2014.02.001

Hilton, D.J., (2001). The Psychology of Financial Decision-Making: Applications to Trading, Dealing, y Investment Analysis. Journal of Psychology y Financial Markets, 2(1), 37-53.

Hirshleifer, D., y Shumway, T. (2003). Good day sunshine: Stock returns y the weather. The Journal of Finance, 58(3), 1009-1032. Retrieved from http://www.jstor.org/stable/3094570

Jacobsen, B., y Marquering, W. (2008). Is it the weather? Journal of Banking y Finance, 32(4), 526-540. doi:http://dx.doi.org/10.1016/j.jbankfin.2007.08.004

Kaplanski, G., y Levy, H. (2010). Exploitable predictable irrationality: The FIFA world cup effect on the U.S. stock market. The Journal of Financial y Quantitative Analysis, 45(2), 535-553. Retrieved from http://www.jstor.org/stable/27801494 
Leshik, E. y Crall, J., (2011). An Introduction to Algorithmic Trading: Basic to Advanced Strategies. Wiley.

Liu, S., (2015). Investor Sentiment y Stock Market Liquidity. Journal of Behavioral Finance, 16(1), pp. 51-67.

Marshall, P. S. (2010). In Kaynak E. H.,TD (Ed.), Sell in may y go away? probably still good investment advice!. HUMMELSTOWN; PO BOX 216, HUMMELSTOWN, PA 17036 USA: INT MANAGEMENT DEVELOPMENT ASSOCIATION-IMDA.

Mishra, V., y Smyth, R. (2010). An examination of the impact of India's performance in one-day cricket internationals on the Indian stock market. Pacific-Basin Finance Journal, 18(3), 319-334. doi:10.1016/j.pacfin.2010.02.005

Moat, H., Cure, C., Abakan, A., Kennett, D. Y., Stanley, H. E., y Pries, T. (2013). Quantifying Wikipedia usage patterns before stock market moves. Scientific Reports, Retrieved fromhttp://www.nature.com/srep/2013/130508/srep01801/pdf/srep01801.pdf

Narayan, S. y Narayan, P.K., (2017). Are Oil Price News Headlines Statistically y Economically Significant for Investors? Journal of Behavioral Finance, 18(3), pp. 258270.

Nofsinguer, J.R., (2005). Social Mood y Financial Economics. Journal of Behavioral Finance, 6(3), pp. 144-160.

Sharpe, W., F., (1994) The Sharpe ratio properly used it can improve investment management, J Portf Manag, 21, pp. 49-58

Yuan, K., Zheng, L., y Zhu, Q. (2006). Are investors moonstruck? lunar phases y stock returns. Journal of Empirical Finance, 13(1), 1-23. doi:http://dx.doi.org/10.1016/j.jempfin.2005.06.001

$\mathrm{Wu}$, Kesheng and Bethel, Wes and Gu, Ming and Leinweber, David and Ruebel, Oliver, A Big Data Approach to Analyzing Market Volatility (June 5, 2013). Algorithmic Finance (2013), 2:3-4, 241-267. Available at SSRN: https://ssrn.com/abstract=2274991 or http://dx.doi.org/10.2139/ssrn.2274991 